\title{
Impact of Servant Leadership Style on Institutional Effectiveness of Public Universities in Ethiopia
}

\author{
Dr Matebe Tafere Gedifew, Co-author \\ Associate Professor of Educational Policy and Leadership at Bahir Dar University, Ethiopia \\ Fentahun Mengistu Bitew, Corresponding Author \\ PhD Candidate in Educational Policy and Leadership at Bahir Dar University, Ethiopia
}

\begin{abstract}
This quantitative study examined servant leadership behavior in public universities of Ethiopia to uncover its impact on institutional effectiveness. The study focused on six major dimensions of servant leadership approach and their impact on the effectiveness of universities. The dimensions included: valuing people, building the community, providing leadership, developing people, sharing leadership and the practice of authenticity. A survey was conducted using cross-sectional research design under probability sampling and a total of 722 participants consisting of instructors, department heads, deans, directors and students were involved in providing data via questionnaires. The collected data were analyzed using both descriptive and inferential statistics. Thus, mean, independent t-test, Pearson's correlation coefficient, linear and multiple regressions were employed. The findings showed that both servant leadership and institutional effectiveness were demonstrated at 'moderate' levels in sample higher education institutions. Positive and significant relationship was also recorded between servant leadership and institutional effectiveness. It was also found that valuing staffs, providing leadership, developing staffs and sharing leadership significantly affect institutional effectiveness of public universities. Thus, leaders in higher education institutions are recommended to implant and exercise servant leadership style vigorously so that they can render the required services and bring about success for their institutions. Besides, researchers are recommended to conduct further longitudinal studies and come up with comprehensive and causative findings that help provide better information for decision makers and practitioners about the study variables in higher education institutions.
\end{abstract}

Keywords: Institutional Effectiveness, Public University, Servant Leadership

DOI: $10.7176 / \mathrm{JEP} / 10-28-02$

Publication date:October $31^{\text {st }} 2019$

\section{Introduction}

In its true sense of leadership, the issue of rendering service to the beneficiaries becomes the decisive point. With no servanthood mindsets and practices, one cannot boldly talk about the existence of true leadership. By its very nature, leadership does mean serving-that is, serving the constituents. A leader must primarily be concerned about his/her deep motive and commitment to serve rather than viewing leadership positions as the best gateways to be served.

Higher education performance in those core functions (i.e., instructions, research works and community outreach services) greatly depend upon leadership as it has significant impact on organizational effectiveness (Choudhary, Akhtar, \& Zaheer, 2013; Muriisa, 2014). In light of this, Muriisa (2014) further noted that "proper leadership in universities remains the missing link for effective and visionary performance.....that universities' performance may not improve until leadership is given critical attention" (p.89). He also extended his discussion by noting that university's effective performance and success are measured in terms of quality educational services such as quality research and publications, teaching and community services rendered to service recipients. In addition, the state of any social organization is largely impacted by leaders' behaviors exhibited in the day-to-day leadership practices (Dierendonck, 2010; Lowe, 2011). Hence, organizations with autocratic leadership cultures characterized by tight controls and excessive directions hinder employees' freedom to think and act independently, and choke their creativities and innovations. Consequently, such leadership practices lead to failures of achieving predefined goals and unable to bring sustainable organizational developments. In this regard, a study by Breeden et al. (2009), indicated that leadership traits characterized by "too much directions and close monitoring leave no space for employees to breath and think independently hampering innovation and learning" (p.2).

Conversely, a leadership approach that capitalizes the active participation of employees in shared leadership and ethical decision making processes has paramount importance in creating healthy organizations and make them effective in their goal attainments. In favor of this, Lowe (2011) argues that a leadership approach that paves the opportunities for employees to demonstrate and allows everyone participate in leadership roles has paramount importance in increasing healthy and effective organizations. He further explained that an organization with follower-centeric perspectives and leadership practices, and a shift in emphasis toward viewing employees as indispensable organizational assets also induce success. Follower-centric leadership practices usually emphasis on 
caring of employees, empowering, creating relationships based on trust and integrity, and inspiring them to be more productive and successful. These leadership attributes also serve as bedrocks for creating healthy and productive organizations with a shared responsibility (Blanchard \& Hodges, 2003; Irving, 2004; Lowe, 2011). On top of this, a study by Sharon, Joseph, David, and Kikelomo (2016) indicated that leadership which gives due regard for people is crucial for realizing organizational success. Leaders of such thinking assume leading as a "privilege to serve others [but not] a display of power or opportunity to accumulate [personal] wealth" (Kolade as cited in Sharon et al., 2016, p.39).

Of all other leadership theories, the findings of many studies show that servant leadership with leader's heightened personal integrity, credibility, trustworthiness, with special focus on followers and enhanced morality has positive linkages with higher and sustainable organizational performance (Blanchard \& Hodges, 2003; Choudhary et al.,2013; Irving, 2004). Servant leaders set standards to be used for measuring performances and provide consistent feedbacks and encouragements with the aim of strengthening employees' and organizational growth and thereby ensure mutual successes. In relation to this, Blanchard and Hodges (2003) have indicated that servant leaders and leadership traits serve as foundations for high performing organizations by creating a compelling vision, values, and a responsive culture via turning the traditional organizational pyramid (hierarchy) upside down or into heterarchy. Grant (as cited in Frick, 2004) further consolidated the idea based on his empirical findings as employees in organizations show better respect and due regard for servant leaders, demonstrate higher morale and confidence when working with servant leaders, and most importantly, more productive and successful. As a result, servant leadership is not only a leadership approach that creates pleasant, trustworthy and vigorous relationships between leaders and followers but also makes followers feel delighted and responsible on their jobs, and invest their utmost knowledge and skills for the organization as well as boost its productivity. Research findings also indicate that there are enhanced employee organizational engagements, effectiveness and creativity when organizations are led by servant leaders and servant leadership philosophy (Grant as cited in Frick, 2004; Piersanti, 2017).

Moreover, servant leadership has a unique concern for followers and organizations rather than focusing on sustaining leadership positions. It is defined as putting and actuating services to others at the forefront of any leadership exercises with enhanced ethical and moral responsibilities. It is selfless leadership act with top priorities in serving and fulfilling the needs of others (customers and stakeholders). While serving, leaders put the needs of their followers and customers first, forsake private benefits and advancements, exercise shared leadership, help followers develop and maximize performance, and seek to learn from their followers. This may also help create conducive working environs with smooth and harmonious leader-follower relationships and goal focused practices which ultimately help make organizations outperform and demonstrate effectiveness.

Even though studies indicating the application of servant leadership in higher education institutions are scarce compared to other business, public and religious institutions, some assert its applicability and paramount importance for enhancing instructional tasks in academic realm. In this regard, Moll and Kretzschmar (2017) argue that servant leadership is more tenable for higher education as it results in improved teaching and research, facilitates execution of leadership responsibilities, promotes "academic collegiality, shared leadership, the retention of academic freedom, and a better balance of academic and managerial power within the university" (p.177). Since the ultimate purpose of servant leadership is serving by leading, its application in higher education institutions enables the academic community exercise essential human values such as morality, integrity, good research, social responsibility and accountability, and being available to one's colleagues, students and other important stakeholders. In relation to this, a study by Dierendonck \& Nuijten (2011) showed that servant leadership is a preferred leadership approach for higher education as it promotes strong employee focus, open communications and short power distance. Moreover, studies conducted by Erkutlu and Chafra (2015); Keith (2010); Shahzad et al. (2013) and Spears (2010) indicated that servant leadership in higher education plays key roles in initiating innovative ideas, creating conducive instructional environments and ensure better academic performances.

Despite this, there is scarcity of researches conducted in Ethiopian context in relation to the applicability of servant leadership for social organizations in general and higher education institutions in particular. Besides, there are no studies made with regard to the relationship between servant leadership and institutional effectiveness at higher education in Ethiopian context. Those few researches done were mainly focused on the applicability of servant leadership at primary schools (Jaleli, 2016; Kediro, 2016; Fikre, 2017; Aytaged, 2014). The studies are directly related to servant leadership practices and the correlation with employee job satisfaction.

Thus, the purpose of this investigation was to examine the impact that applying servant leadership might have on institutional effectiveness in public higher education institutions. In doing so, the following were used as guiding questions for this research endeavor:

1) To what extent do leaders in universities exhibit servant leadership?

2) To what extent do universities are institutionally effective?

3) Is there statistically significant mean difference between instructors and students with regard to the practices 
of servant leadership and institutional effectiveness?

4) Is there statistically significant relationship between servant leadership and institutional effectiveness?

5) To what extent does leaders' servant-leadership practice predict institutional effectiveness?

6) To what extent do the dimensions of servant leadership predict institutional effectiveness?

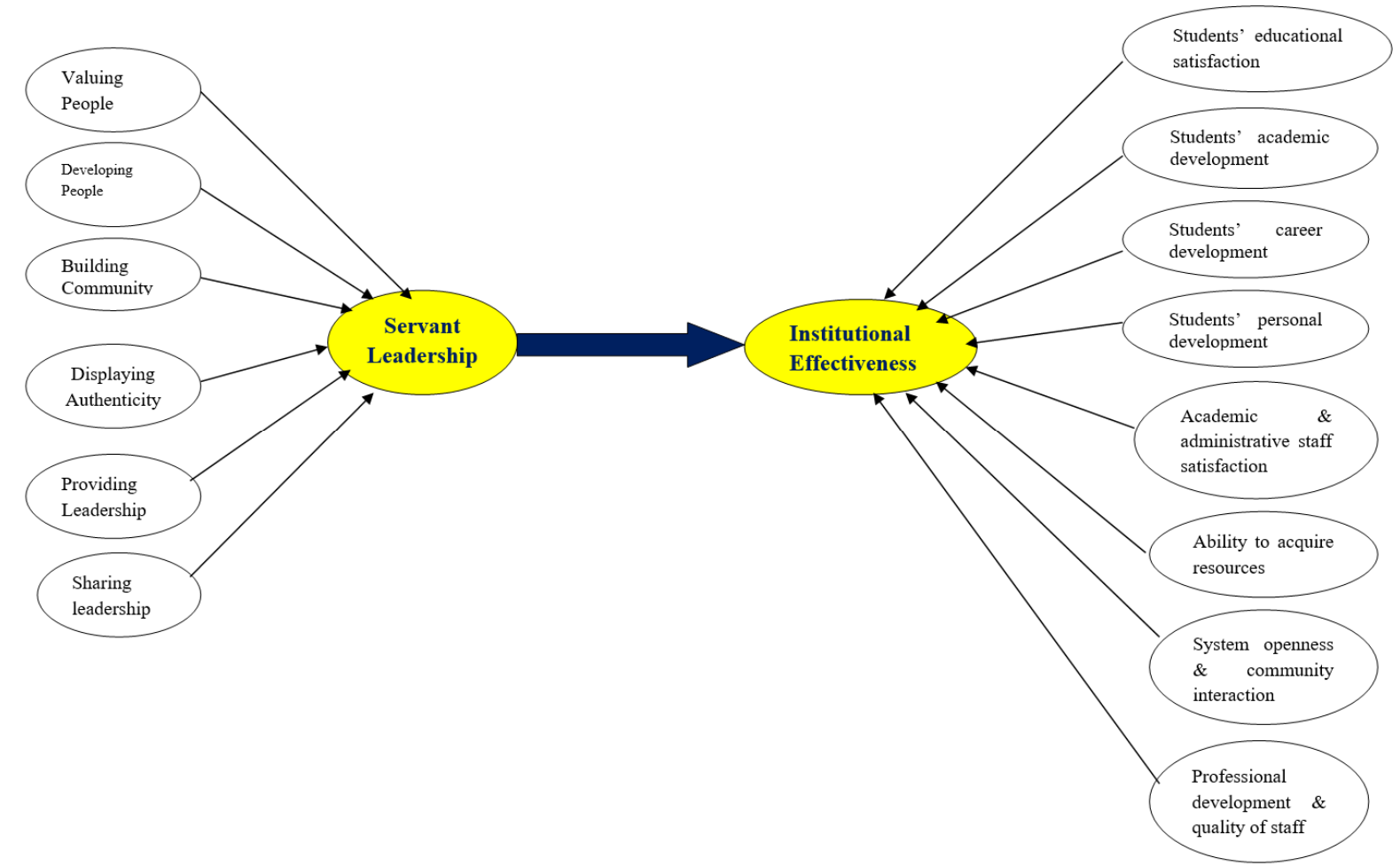

Fig1. Conceptual Framework for the Impact of Servant Leadership on Institutional Effectiveness

\section{Research Methodology}

The study adopted a descriptive survey and correlational research design. It was a cross-sectional research approach. According to Cohen, Manion and Morrison (2007), descriptive survey design is a study which aims at collecting data on, and describing in a systematic manner the characteristics, features or facts about a given population. It was conducted in public universities found in one of the nine national regional states of Ethiopia. According to the current federal arrangements of Ethiopia, the Amhara National Regional State is the largest federal state in its area and population size next to Oromiya National Regional State. Under this national regional state, there are ten public universities. Universities fall under four homogenous groups (strata) of generations: $1^{\text {st }}$, $2^{\text {nd }}, 3^{\text {rd }}$ and $4^{\text {th }}$ generation universities. Each group (generation) consisted of universities nearly with similar characteristics in many aspects such as structures, infrastructures, staff profiles, and so on.

This study however focused on seven universities as a study population excluding the $4^{\text {th }}$ generation universities as they are newly established which lack well established structures, resources, infrastructures, and leadership as well as governance experiences. Hence, one from the first three generations and a total of $3(42.9 \%)$ were selected using stratified sampling technique. Sample universities included in the study were; Bahir Dar University (BDU), Debre Tabor University (DTU) and Debre Birhan University (DBU). Therefore, this design was deemed appropriate for this study which collected data from deans, directors, department heads, instructors and students based on the topic of the study. Besides, $14(41.18 \%)$ deans, $47(23.38 \%)$ department heads, 53 (70.67\%) directors, 278 (58.04\%) instructors and 330 (12.21\%) students were selected using stratified sampling technique.

Standardized questionnaires were adapted from Laub's (1999) servant leadership and Cameroon's (1978) institutional effectiveness dimensions. Hence, the respondents were asked to rate their responses in a 5-point scale of Very High (VH), High (H), Moderate (M), Low (L), and Very Low (VL). A pilot-test, involving 103 participants selected randomly from a university different from the three sample universities, was carried out to check the reliability of the instruments using Pearson's Product moment correlation. Consequently, reliability coefficients of 0.975 and 0.942 were obtained for servant leadership and institutional effectiveness respectively.

The researcher with the help of six research assistants therefore administered the questionnaire to the respondents. Mean and standard deviation were used in answering the research questions that state the practices of servant leadership and institutional effectiveness. The decision rule for interpreting the mean scores of the data 
was 3.0. An independent t-test was also employed to compare the mean differences between the responses of instructors and students at 0.05 alpha levels. In addition, simple linear correlation was employed to determine the association between servant leadership and institutional effectiveness. Moreover, linear and multiple regressions were employed to evaluate the effect size of an independent variable (servant leadership) on the dependent variable (institutional effectiveness); and the effects of servant leadership dimensions on institutional effectiveness respectively.

\section{Results}

The study involved 722 participants consisting of instructors, department heads, deans, directors and students for data collection via questionnaires. Of which, $621(86.01 \%)$ copies of the questionnaires were retrieved from the respondents, making a total of $557(89.69 \%)$ copies duly filled and returned. Consequently, the collected data were analyzed for each variable as indicated in the following tables.

Table1. Descriptive Statistics for Servant Leadership

\begin{tabular}{|c|c|c|c|c|c|c|c|}
\hline \multirow[t]{2}{*}{ Dimensions } & & \multirow[t]{2}{*}{$\mathrm{N}$} & \multirow[t]{2}{*}{ Mean } & \multirow[t]{2}{*}{$\begin{array}{c}\text { Std. } \\
\text { Deviation }\end{array}$} & \multirow[t]{2}{*}{$\begin{array}{l}\text { Std. Error } \\
\text { Mean }\end{array}$} & \multicolumn{2}{|c|}{$\begin{array}{l}95 \% \text { Confidence Interval of the } \\
\text { Difference }\end{array}$} \\
\hline & & & & & & Lower & Upper \\
\hline \multirow{3}{*}{ Valuing People } & 1 & 196 & 2.8031 & .65052 & .04647 & -.2886 & -.1053 \\
\hline & 2 & 161 & 3.4559 & .80350 & .06332 & .3308 & .5810 \\
\hline & 3 & 200 & 3.7170 & .71826 & .05079 & .6168 & .6168 \\
\hline \multirow{4}{*}{ Developing People } & 1 & 196 & 2.8490 & .72752 & .05197 & -.2535 & -.0485 \\
\hline & 2 & 161 & 3.3155 & .88421 & .06969 & .1779 & .4531 \\
\hline & 3 & 200 & 3.6120 & .62112 & .04392 & .5254 & .5254 \\
\hline & 1 & 196 & 2.8737 & .72876 & .05205 & -.2289 & -.0236 \\
\hline \multirow[t]{3}{*}{ Building Community } & 2 & 161 & 3.4736 & .78740 & .06206 & .3510 & .5962 \\
\hline & 3 & 200 & 3.7300 & .59592 & .04214 & .6469 & .6469 \\
\hline & 1 & 196 & 2.7937 & .65970 & .04712 & -.2992 & -.1133 \\
\hline \multirow[t]{3}{*}{ Display Authenticity } & 2 & 161 & 3.4543 & .82312 & .06487 & .3262 & .5824 \\
\hline & 3 & 200 & 3.6471 & .63613 & .04498 & .5584 & .5584 \\
\hline & 1 & 196 & 2.8214 & .66741 & .04767 & -.2726 & -.0846 \\
\hline \multirow[t]{3}{*}{ Provide Leadership } & 2 & 161 & 3.3872 & .84648 & .06671 & .2554 & .5189 \\
\hline & 3 & 200 & 3.6867 & .64637 & .04571 & .5965 & .5965 \\
\hline & 1 & 196 & 2.7589 & .72518 & .05180 & -.3432 & -.1389 \\
\hline \multirow[t]{3}{*}{ Share Leadership } & 2 & 161 & 3.3370 & .89148 & .07026 & .1982 & .4757 \\
\hline & 3 & 200 & 3.6525 & .69717 & .04930 & .5553 & .5553 \\
\hline & 1 & 196 & 2.9084 & .61309 & .04379 & -.1780 & -.0052 \\
\hline \multirow[t]{2}{*}{${ }^{*}$ Servant Leadership } & 2 & 161 & 3.5079 & .77173 & .06082 & .3878 & .6281 \\
\hline & 3 & 200 & 3.7834 & .56939 & .04026 & .7040 & .7040 \\
\hline
\end{tabular}

$\mathbf{1}=$ Bahir Dar University (BDU); $\mathbf{2}=$ Debre Tabor University (DTU); $\mathbf{3}=$ Debre Birhan University (DBU)

The mean and standard deviations were calculated to understand the level of the practices of servant leadership and its dimensions. As shown in Table1, the results are above average for DBU (Mean=3.7834, $\mathrm{SD}=0.56939)$ and DTU (Mean=3.5079, $\mathrm{SD}=0.77173)$ but slightly below average for $\mathrm{BDU}(\mathrm{Mean}=2.9084, \mathrm{SD}=$ 0.61309). When we look at the means and standard deviations of each servant leadership dimensions, the findings showed that all of them were manifested with different magnitudes from above average to slightly below average levels in the study contexts (see Table1). Therefore, from the results of the survey data, it is possible to understand that servant leadership behaviors are manifested by leaders at 'moderate' level in sample universities.

Compared to other servant leadership dimensions, building the community was better demonstrated by leaders in all sample universities (Means \& Standard Deviations $=2.8737 \& 0.72876 ; 3.4736 \& 0.78740$, and $3.7300 \& 0.59592$ respectively). This means that leaders are good at resolving difficult issues in a timely way, facilitating team spirit, valuing and respecting diversity issues related to culture, ethnicity, skills and abilities amongst staffs and students in their respective working environs. In addition, they showed better performances in creating cohesiveness and bringing staffs together that help them secure improved performances and goal achievements. But for BDU, the data showed that leaders' commitment in sharing power to staffs to make decisions by their own and enabling them exercise leadership in the assigned work units have given relatively less emphasis compared to the other servant leadership dimensions. For the other two universities (DTU \& DBU), leaders' commitment and performance in developing people found relatively weak. This does mean that leaders competence and commitment in creating an environment which promotes learning and growth for staffs, leading others by modeling appropriate behaviors, providing mentoring supports for staffs to grow professionally, and viewing conflicts as better opportunities for learning and growth are relatively at lower implementation stages (see 
Table1).

Therefore, despite its rigor and consistency, one may say that behaviors associated to servant leadership theory are demonstrated 'moderately' by leaders in public universities.

Table2. Descriptive Statistics for Institutional Effectiveness

\begin{tabular}{|c|c|c|c|c|c|c|c|}
\hline \multirow[t]{2}{*}{ Dimensions } & & \multirow[t]{2}{*}{$\mathrm{N}$} & \multirow[t]{2}{*}{ Mean } & \multirow[t]{2}{*}{$\begin{array}{c}\text { Std. } \\
\text { Deviation }\end{array}$} & \multirow[t]{2}{*}{$\begin{array}{l}\text { Std. Error } \\
\text { Mean }\end{array}$} & \multicolumn{2}{|c|}{$\begin{array}{l}95 \% \text { Confidence Interval } \\
\text { of the Difference }\end{array}$} \\
\hline & & & & & & Lower & Upper \\
\hline \multirow{3}{*}{$\begin{array}{l}\text { Students } \\
\text { Satisfaction }\end{array}$} & 1 & 196 & 2.8610 & .75795 & .05414 & 2.7542 & 2.9677 \\
\hline & 2 & 161 & 3.4457 & .88684 & .06989 & .3076 & .5837 \\
\hline & 3 & 200 & 3.5254 & .71051 & .05024 & .4263 & .4263 \\
\hline & 1 & 196 & 2.8520 & .66683 & .04763 & 2.7581 & 2.9460 \\
\hline \multirow{2}{*}{$\begin{array}{l}\text { Students } \\
\text { Development }\end{array}$} & 2 & 161 & 3.4576 & .84723 & .06677 & .3257 & .5894 \\
\hline & 3 & 200 & 3.5125 & .68218 & .04824 & .4174 & .4174 \\
\hline \multirow{3}{*}{$\begin{array}{l}\text { Students } \\
\text { Development }\end{array}$} & 1 & 196 & 2.9923 & .85256 & .06090 & 2.8722 & 3.1124 \\
\hline & 2 & 161 & 3.1615 & 1.00717 & .07938 & .0047 & .3183 \\
\hline & 3 & 200 & 3.1615 & 1.00717 & .07938 & .0047 & .3183 \\
\hline \multirow{3}{*}{$\begin{array}{l}\text { Students } \\
\text { Development }\end{array}$} & 1 & 196 & 2.7946 & .67338 & .04810 & 2.6998 & 2.8895 \\
\hline & 2 & 161 & 3.3882 & .82154 & .06475 & .2603 & .5161 \\
\hline & 3 & 200 & 3.5813 & .68771 & .04863 & .4854 & .4854 \\
\hline \multirow{4}{*}{$\begin{array}{l}\text { Academic \& Administrative } \\
\text { Staff Satisfaction }\end{array}$} & 1 & 196 & 2.7483 & .64594 & .04614 & 2.6573 & 2.8393 \\
\hline & 2 & 161 & 3.2298 & .84017 & .06621 & .0990 & .3606 \\
\hline & 3 & 200 & 3.5767 & .61045 & .04317 & .4915 & .4915 \\
\hline & 1 & 196 & 2.7526 & .73292 & .05235 & 2.6493 & 2.8558 \\
\hline \multirow[t]{2}{*}{ Ability to Acquire Resources } & 2 & 161 & 3.0342 & 1.03851 & .08185 & -.1275 & .1958 \\
\hline & 3 & 200 & 3.5325 & .67078 & .04743 & .4390 & .4390 \\
\hline \multirow{3}{*}{$\begin{array}{l}\text { System } \quad \text { Openness } \\
\text { Community Interaction }\end{array}$} & 1 & 196 & 2.8367 & .70447 & .05032 & 2.7375 & 2.9360 \\
\hline & 2 & 161 & 3.3188 & .96850 & .07633 & .1681 & .4696 \\
\hline & 3 & 200 & 3.5450 & .67016 & .04739 & .4516 & .4516 \\
\hline \multirow{3}{*}{$\begin{array}{l}\text { Professional Development \& } \\
\text { Quality of Staff }\end{array}$} & 1 & 196 & 2.7670 & .80286 & .05735 & 2.6539 & 2.8801 \\
\hline & 2 & 161 & 3.4327 & .88022 & .06937 & .2957 & .5697 \\
\hline & 3 & 200 & 3.3341 & .66200 & .04681 & .2418 & .2418 \\
\hline \multirow{3}{*}{ *Institutional Effectiveness } & 1 & 196 & 3.2869 & .60443 & .04317 & 3.2017 & 3.3720 \\
\hline & 2 & 161 & 3.8637 & .82145 & .06474 & .7359 & .9916 \\
\hline & 3 & 200 & 4.0332 & .59377 & .04199 & .9504 & .9504 \\
\hline
\end{tabular}

Investigating the status of institutional effectiveness in higher education institutions was another task of this research endeavor. Hence, as it was portrayed in Table2, for all sample universities the results showed above average or threshold (i.e., 3.00) and participants of this survey rated from 'moderate to high levels' to indicate the status of institutional effectiveness in their respective university. And the mean values and standard deviations were: BDU (Mean=3.2869, SD=0.60443), DTU (Mean=3.3.8637, SD=0.82145) and $\mathrm{DBU}(\mathrm{Mean}=4.0332$, $\mathrm{SD}=0.59377$ ). When we look at the mean values for the practice of each dimension of institutional effectiveness, students career development (BDU, Mean=2.9923); students academic development (DTU, Mean=3.4576); and students personal development (DBU, Mean=3.5813) were exhibited relatively at higher magnitudes. On the other hand, comparatively speaking, administrative staff satisfaction for BDU (Mean=2.7483, SD=0.64594) and students' career satisfaction for DTU (Mean=3.0342, SD=1.00717) and DBU (Mean=2.9900, SD=0.99617) were found relatively at lower magnitudes.

\subsection{Statistical Tests for Mean Difference between Groups (Instructors \& Students)}

Comparing the mean differences of the responses obtained from instructors and students was made to investigate the variations in views about the extent of the practice of each variable in the study context. 
Table3. Independent t-test of the perceptions between instructors and students pertaining to servant leadership and institutional effectiveness at BDU

\begin{tabular}{|c|c|c|c|c|c|c|c|c|c|c|}
\hline \multirow{3}{*}{ Variables } & \multirow{3}{*}{ Groups } & \multirow{3}{*}{ Mean } & \multirow{3}{*}{ SD } & \multirow{3}{*}{$\mathbf{t}$} & \multirow{3}{*}{ df } & \multicolumn{3}{|c|}{ t-test for Equality of Means } & \multirow{2}{*}{\multicolumn{2}{|c|}{$\begin{array}{c}95 \% \\
\text { Confidence } \\
\text { Interval of the } \\
\text { Difference }\end{array}$}} \\
\hline & & & & & & \multirow[t]{2}{*}{$\begin{array}{l}\text { Sig. } \\
(2- \\
\text { tailed })\end{array}$} & \multirow[t]{2}{*}{$\begin{array}{c}\text { Mean } \\
\text { Difference }\end{array}$} & \multirow[t]{2}{*}{$\begin{array}{l}\text { Std. Error } \\
\text { Difference }\end{array}$} & & \\
\hline & & & & & & & & & Lower & Upper \\
\hline & Instructors & 2.9408 & .68473 & & & & & & & \\
\hline Servant Leadership & Students & 2.8703 & .60645 & .706 & 166 & .481 & .07043 & .09973 & -.12648 & .26734 \\
\hline $\begin{array}{l}\text { Institutional } \\
\text { Effectiveness }\end{array}$ & $\begin{array}{l}\text { Instructors } \\
\text { Students }\end{array}$ & $\begin{array}{l}3.3399 \\
3.1819 \\
\end{array}$ & $\begin{array}{l}.63178 \\
.62325\end{array}$ & 1.631 & 166 & .105 & .15796 & .09683 & -.03322 & .34913 \\
\hline
\end{tabular}

Table 3 above displayed that the mean value for servant leadership is below the average or threshold, and both instructors and students rated slightly below the average to describe the extent of the practice of this variable in the university. But, concerning the status of institutional effectiveness, the mean value is above the average or threshold. This indicates that both instructors and students rated the extent of the practice of the variable as 'moderate' or they have the perception that behaviors related to institutional effectiveness are demonstrated 'moderately' by leaders and employees in the institution.

The result of an independent samples t-test also depicted that there was no statistically significant mean difference between instructors and students with regard to the extent of the practice of the variables (i.e., for servant leadership: $\mathrm{t}_{(166)}=0.706, \mathrm{p}=0.481$ and institutional effectiveness: $\left.\mathrm{t}_{(166)}=1.631, \mathrm{p}=0.105\right)$. The magnitude of the difference in the mean between groups was very small (i.e., mean differences for servant leadership $=0.07043,95 \%$ $\mathrm{CI}=-.12648$ to .26734 and institutional effectiveness $=0.15796,95 \% \mathrm{CI}=-.03322$ to .34913$)$. Therefore, based on the results of an independent t-test, it is possible to say that with 95\% confidence level, groups (instructors and students) had closely related evaluations with regard to the extent of the practice of each variable at BDU.

Table4. Independent t-test of the perceptions between instructors and students pertaining to servant leadership and institutional effectiveness at DTU

\begin{tabular}{|c|c|c|c|c|c|c|c|c|c|c|}
\hline \multirow{3}{*}{ Variables } & \multirow{3}{*}{ Groups } & \multirow{3}{*}{ Mean } & \multirow{3}{*}{ SD } & \multirow{3}{*}{$\mathbf{t}$} & \multirow{3}{*}{ df } & \multicolumn{3}{|c|}{ t-test for Equality of Means } & \multirow{2}{*}{\multicolumn{2}{|c|}{$\begin{array}{c}95 \% \\
\text { Confidence } \\
\text { Interval of the } \\
\text { Difference }\end{array}$}} \\
\hline & & & & & & $\begin{array}{c}\text { Sig. } \\
(2- \\
\text { tailed) }\end{array}$ & $\begin{array}{c}\text { Mean } \\
\text { Difference }\end{array}$ & $\begin{array}{l}\text { Std. Error } \\
\text { Difference }\end{array}$ & & \\
\hline & & & & & & & & & Lower & Upper \\
\hline Servant Leadership & $\begin{array}{l}\text { Instructors } \\
\text { Students }\end{array}$ & $\begin{array}{l}3.3826 \\
3.7689\end{array}$ & $\begin{array}{l}.77228 \\
75695\end{array}$ & $\begin{array}{c}- \\
2920\end{array}$ & 132 & .004 & -.38632 & .13230 & -.64803 & -.12461 \\
\hline $\begin{array}{l}\text { Institutional } \\
\text { Effectiveness }\end{array}$ & $\begin{array}{l}\text { Instructors } \\
\text { Students }\end{array}$ & $\begin{array}{l}3.7416 \\
4.1054 \\
\end{array}$ & $\begin{array}{l}.73859 \\
.91365 \\
\end{array}$ & 2.545 & 132 & .012 & -.36385 & .14299 & -.64669 & -.08100 \\
\hline
\end{tabular}

As shown in Table 4, both instructors and students rated the extent of the practices of the variables from 'moderate' to 'high' levels. The result of the mean difference for each variable was also statistically significant (i.e., servant leadership, $\mathrm{t}_{(132)}=-2.920, \mathrm{p}<0.004$ and institutional effectiveness, $\mathrm{t}_{(132)}=-2.545, \mathrm{p}<0.012$ ). Besides, the magnitude of the difference in the mean between groups was large (i.e., the mean differences for: servant leadership $=-.38632,95 \% \mathrm{CI}=-.64803$ to -.12461 and institutional effectiveness $=-.36385,95 \% \mathrm{CI}=-.64669$ to -.08100). Therefore, based on the results of an independent t-test, it is possible to say that with $95 \%$ confidence level, groups (instructors and students) had quite different evaluations with regard to the extent of the practice of each variable in the university. Besides, for all cases, the probabilities are less than 0.05 alpha level and students had higher mean values than instructors in evaluating the practices and prevalence of variables in the university (see Table4). This implies that students with high mean values appear to have better positive evaluations about the practices of the variables in their own context (DTU) as compared to instructors. 
Table5. Independent t-test of the perceptions between instructors and students pertaining to servant leadership and institutional effectiveness at DBU

\begin{tabular}{|c|c|c|c|c|c|c|c|c|c|c|}
\hline \multirow{3}{*}{ Variables } & \multirow{3}{*}{ Groups } & \multirow{3}{*}{ Mean } & \multirow{3}{*}{ SD } & \multirow{3}{*}{$\mathbf{t}$} & \multirow{3}{*}{ df } & \multicolumn{5}{|c|}{ t-test for Equality of Means } \\
\hline & & & & & & $\begin{array}{l}\text { Sig. } \\
(2- \\
\text { tailed })\end{array}$ & $\begin{array}{c}\text { Mean } \\
\text { Difference }\end{array}$ & $\begin{array}{l}\text { Std. Error } \\
\text { Difference }\end{array}$ & $\begin{array}{r}95 \% \text { Cor } \\
\text { Interva } \\
\text { Diffe }\end{array}$ & $\begin{array}{l}\text { nfidence } \\
\text { l of the } \\
\text { rence }\end{array}$ \\
\hline & & & & & & & & & Lower & Upper \\
\hline Servant Leadership & $\begin{array}{l}\text { Instructors } \\
\text { Student }\end{array}$ & $\begin{array}{l}3.5948 \\
3.7620\end{array}$ & $\begin{array}{l}.30288 \\
.65547\end{array}$ & $\begin{array}{c}- \\
2.170\end{array}$ & 170 & .031 & -.16715 & .07701 & -.31918 & -.01513 \\
\hline $\begin{array}{l}\text { Institutional } \\
\text { Effectiveness }\end{array}$ & $\begin{array}{l}\text { Instructors } \\
\text { Student }\end{array}$ & $\begin{array}{l}3.8481 \\
4.0720\end{array}$ & $\begin{array}{l}.32444 \\
.71778\end{array}$ & $\begin{array}{c}- \\
2.666\end{array}$ & 170 & .008 & -.22392 & .08399 & -.38972 & -.05811 \\
\hline
\end{tabular}

The result of an independent sample t-test in Table 5 depicted that there were significant mean differences between groups with regard to the evaluation of the practices of servant leadership and institutional effectiveness in the university $\left(\mathrm{t}_{(170)}=-2.170, \mathrm{p}<0.031\right.$, and $\mathrm{t}_{(170)}=-2.666, \mathrm{p}<0.008$ respectively). For both cases, the probabilities are less than the alpha level (0.05). Besides, the mean values of students' evaluation with regard to the manifestations of servant leadership behaviors and institutional effectiveness were higher than the mean values of instructors' evaluation (see Table5). This shows that students had positive views and evaluations about the practice of servant leadership and the status of institutional effectiveness at DBU.

\subsection{Correlation between Servant Leadership and Institutional Effectiveness}

Under this sub-section, linear relationship and multiple linear regression analyses were made to examine the correlations between variables and the effect sizes or coefficient of determinations. Linear regression was made to examine the effect of servant leadership on institutional effectiveness. Besides, multiple linear regression analysis was made to examine the combined effect of servant leadership (SL) dimensions on institutional effectiveness (IE) at higher education institutions.

Table6. Linear Relationship between Servant Leadership and Institutional Effectiveness

\begin{tabular}{cccc}
\hline Variables & & 1 & 2 \\
\hline \multirow{3}{*}{ Servant Leadership } & Pearson Correlation & 1.00 & - \\
& Sig. (2-tailed) & 557 & - \\
Institutional Effectiveness & $\mathrm{N}$ & $.751^{* *}$ & 1.00 \\
& Pearson Correlation & & 557 \\
\hline
\end{tabular}

**. Correlation is significant at 0.05

One of the basic questions was focused on investigating whether there is a correlation between SL and IE. Thus, as it was indicated in Table6, the Pearson correlation coefficient result indicated that there is a strong positive relation between the variables. That is, SL showed strong positive relationship to IE with the coefficient of $\mathrm{r}=0.751$. According to the McMillan's (1992) criteria, the correlation is also strong or high between the variables. Therefore, based on the result of the Pearson correlation coefficient, one may say that the variables mentioned above have direct positive relationship between them. That is, as leaders in higher education institutions apply servant leadership style in their day-to-day leadership exercises, they may ensure institutional effectiveness in their respective working contexts.

Table7. Linear Regression Statistics of Servant Leadership on Institutional Effectiveness

\begin{tabular}{cccccccc}
\hline Model & $\mathrm{R}$ & $\mathrm{R}^{2}$ & Adjusted R $^{2}$ & Std. Error & Beta & $\mathrm{t}$ & Sig. \\
\hline 1 & $.751^{\mathrm{a}}$ & .564 & .563 & .49308 & .751 & 26.801 & .000 \\
\hline
\end{tabular}

a. Dependent Variable: Institutional Effectiveness

Another basic question raised was aimed at investigating the coefficient of determination of servant leadership on institutional effectiveness. Consequently, the results of linear regression in table 7 indicated that $0.564(56.4 \%)$ of the variability for institutional effectiveness was accounted by the effect of servant leadership style exhibited in higher education institutions. When compared with the amount of coefficient of non-determination or coefficient of alienation which accounts for $43.6 \%$, the effect of the above variable was significant. The model was also a good fit and statistically significant for the data used for this regression analysis $\left(F_{(\mathbf{1}, 556)}=718.307, p<0.001\right)$. 
Table8. Multiple Linear Regressions

\begin{tabular}{|c|c|c|c|c|c|c|}
\hline Dimensions & $\mathrm{R}$ & $\mathrm{R}^{2}$ & Std. Error & Beta & $\mathrm{t}$ & sig. \\
\hline Valuing people & $.762^{\mathrm{a}}$ & .581 & .48560 & .157 & 3.398 & .001 \\
\hline Developing people & & & & .232 & 4.229 & .000 \\
\hline Building community & & & & .030 & .602 & .548 \\
\hline Displaying authenticity & & & & .016 & .263 & .793 \\
\hline Providing leadership & & & & .240 & 4.638 & .000 \\
\hline Sharing leadership & & & & .184 & 3.956 & .000 \\
\hline
\end{tabular}

a. Dependent Variable: Institutional Effectiveness

Investigating the predictive power of the dimensions of servant leadership was another concern of the study. Hence, the result of multiple regressions analysis revealed that $0.762(76.2 \%)$ of the variability for institutional effectiveness was accounted by the composite effect of the dimensions of servant leadership exhibited in higher education institutions. When compared with the amount of coefficient of non-determination or coefficient of alienation which accounts for $23.8 \%$, the combined effect of the above dimensions was significant and strong. The model was also a good fit and statistically significant for the data used for this regression analysis $\left(\mathrm{F}_{(6,556)}=127.134\right.$, $\mathrm{p}<0.001)$. The direct effect of each independent dimension on institutional effectiveness was also examined using beta coefficients. Thus, the effects of valuing staffs $(B=0.157, t=3.398, p<0.001)$, developing staffs $(B=-0.232$, $\mathrm{t}=4.229, \mathrm{p}<0.001)$, providing leadership $(\mathrm{B}=0.240, \mathrm{t}=4.638, \mathrm{p}<0.001)$ and sharing leadership $(\mathrm{B}=0.184, \mathrm{t}=3.956$, $\mathrm{p}<0.001)$ on institutional effectiveness were statistically significant. That is to say, $15.7 \%, 23.2 \%, 24 \%$ and $18.4 \%$ of institutional effectiveness was accounted by leaders' practices in valuing staffs, developing people in the university, providing leadership and sharing leadership respectively. Whereas building the university community $(B=-0.037, t=0.030, P>0.05)$ and displaying authenticity $(B=0.016, t=0.263, p>0.05)$, showed not statistically significant effects on institutional effectiveness. As a result, 3.7\% and $1.6 \%$ of changes in institutional effectiveness was accounted by these servant leadership dimensions respectively.

\section{Discussion}

The findings revealed that servant leadership behaviors are exhibited by leaders in universities despite differences in their magnitudes. That is, university leaders at different layers demonstrated 'moderate' levels of practices for most behaviors of servant leadership. However, the results contradict with the findings of Firew, Mitiku \& Mebratu (2016), Lerra (2015) and Kassahun (2015) which state that higher education institutions are in short of servant leaders deep-rooted in moral teaching and feelings of professionalism, and those who view leading as an opportunity and responsibility to serve staffs, students and the community at large. Such studies also indicated that often leaders in higher education institutions fail to assume themselves as servants to their followers, and reluctant to make themselves accountable for and take responsibilities for instructional failures. In addition, the research findings of Getachew (2014), Getachew \& Richard, (2006), and Behailu (2011) augmented the idea that officious and autocratic leadership cultures manifested by leaders of higher education institutions are common practices that lead to institutional ineffectiveness. Likewise, the findings of the research showed that institutional effectiveness in higher education institutions was exhibited from 'moderate' to 'high' levels (see Table2). But studies carried out by Getachew and Richard (2006) disfavored the above findings by stating that despite diverse initiatives and commitments made at public civil service organizations including higher education institutions, their effectiveness in performances are far less and even their achievements are widely different from institution to institution.

Yet, studies indicate that higher education institutions are required to make a balance of unlimited demands and interests arising from different sources and bring institutional effectiveness ( Smart et al., 1997 cited in Pounder, 2001). Moreover, effectiveness in educational institutions is possible among other things by employing servant leadership practices (Greenleaf, 1977; Keith, 2011). The writings of these scholars also strongly argue that leaders exercising servant leadership behaviors make employees perform at their highest capacity and result in effective institutions. By the same token, leaders committed to serving by leading in higher education institutions often focus on educational issues such as students' holistic developments, staffs' professional development, system openness and community interaction as well as strive to create healthy institutions (Muriisa, 2014). As servant leadership lays the foundation for higher institutional purpose, values human dignity and mutual respect as well as focuses on serving others truly, it is the preferred gateway and approach for ensuring institutional effectiveness. In relation to this, Wong and Page (2003) stated that servant leadership attributes such as shared leadership and decision-making, responsibility, and accountability help bring institutional effectiveness.

Moreover, the findings showed that a strong positive relationship is recorded between servant leadership and institutional effectiveness (see Table6). This finding is also in line to the research results of Blanchard and Hodges (2003), Breeden et al., (2009), Choudhary et al. (2013) and Irving (2004). Studies made by these scholars also identified that servant leaders and leadership traits serve as foundations for high performing organizations by creating a compelling vision, values, and a responsive culture via turning the traditional organizational pyramid (hierarchy) upside down or into heterarchy. Significant effects have also shown on the performance and 
effectiveness of higher education institution as a result of employing servant leadership behaviors (Boume, 2016; Manala, 2014).

\section{Conclusions}

A number of studies showed that leadership plays key roles in creating effective institutions and making them reputable as well as competent in all aspects mandated. The same is true for higher education institutions. With three pillars mandated to higher education institutions (instructional processes, research activities and community services), demonstrating effectiveness and efficiencies becomes an indisputable expectations from all stakeholders and beneficiaries. This study therefore attempts to investigate to what extent leaders' servant leadership exercises impact on institutional effectiveness in public higher education institutions. Hence, the results showed that the calculated mean values for servant leadership and institutional effectiveness are close to and above the threshold or average. From this, we may conclude that despite differences in magnitudes, leaders in sample higher education institutions exhibited behaviors associated to both servant leadership and institutional effectiveness. The result of the Pearson correlation coefficient also showed that servant leadership is strongly and positively correlated with institutional effectiveness. As a result, one may construe that as the rigor of the practice of servant leadership in higher education institutions increases, the institutional effectiveness will undoubtedly raise up. In addition, this study was looked at the impacts that the dimensions of servant leadership have on institutional effectiveness of higher education institutions. Consequently, the results showed that except two of the indicators (building the community and displaying authenticity), the other servant leadership indicators or dimensions have showed statistically significant effects on institutional effectiveness in higher education institutions. From this, one may come up with the conclusion that applying servant leadership indicators or dimensions in higher education institutions have significant contributions for institutional effectiveness. But the contributions of two of servant leadership dimensions stated above didn't show significant contributions in determining institutional effectiveness. As a result, exercising those servant leadership dimensions with significant contributions will bring improved results for higher education effectiveness.

\section{Recommendations}

The findings of this study and other related studies in other contexts confirmed that employing servant leadership theory in higher education institutions has paramount contributions. As a new leadership style with the quest to render services, instilling and institutionalizing servant leadership in higher education institutions becomes so crucial. As a result, it is recommended that leaders in higher education institutions apply servant leadership style vigorously so that they can render the required services and ensure success of their institutions. Though, the results of the correlation analyses showed significant and positive relationships between servant leadership and institutional effectiveness, they cannot show causality. Therefore, researchers are recommended to conduct further longitudinal studies and come up with comprehensive and causative findings that help provide better information for decision makers and practitioners about the study issues. In addition, information about the impacts brought by servant leadership up on institutional effectiveness will be better verified. Besides, this study was done in public higher education institutions found in a single national regional state and hence, it is advisable that researchers conduct similar studies in higher education institutions at national level so that comprehensive understanding about the level of the practices of the variables could be obtained.

\section{References}

Aytaged, Sisay (2014). A call for a leadership style change in Ethiopian higher education. The Ethiopian Journal of Education, XXXIV (2), 131-143.

Behailu, A. (2011). The path of governance transformation in Ethiopian higher education- institutional perspective: A tale of three universities experience with respect to BPR reform. Unpublished Thesis for European Master in Higher Education (HEEM), University of Oslo, Norway.

Blanchard, K. \& Hodges, P. (2003). The Servant Leader: Transforming Your Heart, Head, Hands \& Habits. Nashville: J. Countryman.

Breeden, et al. (2009). Building healthy organizations to drive performance. The evidence, McKinsey \& Company. Boume, PA (2016). Leadership as a service: A new model for higher education in a new century - A Book Review. Review Public Administration Management 4:196. doi:10.4172/2315-7844.1000196

Cameroon, K. (1978). Measuring organizational effectiveness in institutions of higher education. Administrative Science Quarterly, 23, 604-632.

Choudhary, I., Akhtar, S. \& Zaheer, A. (2013). Impact of transformational and servant leadership on organizational performance: A comparative analysis. Journal of Business Ethics, 116, 433-440.

Cohen, L., Manion, L, \& Morrison, K. (2007). Research methods in education. ( $6^{\text {th }}$ ed.), New York, NY: Routledge

Dierendonck, D. (2010). Servant Leadership: A review and synthesis. Journal of Management, 37(4), 1228-1261.

Dierendonck, D. (2011). Servant Leadership: A review and synthesis. Journal of Management, 37(4), 1228-1261. 
Erkutlu, H. \& Chafra, J. (2015). Servant leadership and voice behavior in higher education. Hacettepe University Journal of Education,30(4),29-41.

Fikre Lobago (2017). Servant leadership practices and its correlation with employee job satisfaction: The Case of Compassion International in Ethiopia. Unpublished MA Thesis, St.Mary's University, Ethiopia

Firew, A., Mitiku, B. \& Mebratu, T. (2016). The ethical behaviors of educational leaders in Ethiopian public universities: The case of western cluster universities. European Scientific Journal, 12(13), 359-379.

Frick, D. (2004). What is a servant leader? Berrett Koehler Publishers Blog

Getachew. H., and Richard, C., (2006).Civil service reform in Ethiopia: Success in two ministries. UK: Center for management and organizational learning.

Getachew, S. (2014). An assessment on the colleges of teacher education staffs' perception on ethical leadership behavior and practice of their leaders in Oromiya Regional State. Unpublished MA Thesis, Addis Ababa University, Addis Ababa

Greenleaf, R. (1977). Servant leadership: A journey into the nature of legitimate power and greatness. New York: Paulist Press.

Irving, J. (2004). Utilizing the leadership assessment as a strategic tool for increasing the effectiveness of teams within organizations. Journal Management and Marketing Research, 111-124.

Jaleli, M. (2016). The state of servant leadership style in the Catholic secondary schools in Addis Ababa. Unpublished MA Thesis, Addis Ababa University, Ethiopia.

Kassahun, K. (2015). Academic governance in public and private universities in Ethiopia: A comparative case study. Unpublished PhD Dissertation, Addis Ababa, Ethiopia: Addis Ababa University

Kediro, J. (2016). The practice of servant leadership for school improvement program in secondary schools of West Arsi Zone of Oromia National Regional State. Unpublished MA Thesis, Haramaya University, Ethiopia.

Keith, K. (2010). Servant leadership in higher education: Issues and concerns. Palm Beach, Florida: Palm Beach Atlantic University.

Keith, K. (2011). Servant leadership in the boardroom: Fulfilling the public trust. Westfield: The Greenleaf Center for Servant Leadership.

Laub, A. (1999). Development of the organizational leadership assessment (OLA) instrument (Doctoral Dissertation).

Retrieved

from http://www.olagroup.com/Images/mmDocument/Laun\%20Dissertation\%20brief.pdf

Lerra, M. (2015). Leadership challenges to transformative change for quality education in public universities: A case of Wolayta Sodo University. African Education Research Journal, 3(3), 170-183.

Lowe, G. (2011). Creating healthy organizations. Toronto, ON: University of Toronto Press.

Manala, M. (2014). Servant leadership: A required leadership model for efficient and effective service delivery in a democratic South Africa. Studia Historiae Ecclesiasticae, 40,249-266.

Moll, J. \& Kretzschmar, L. (2017). An investigation of the suitability of a servant leadership model for academic group leaders at German Universities. Journal of Leadership Education, 16(12), 166-182.

Muriisa, R. (2014). Rethinking the role of universities in Africa: Leadership as a missing link in explaining university performance in Uganda. JHEA/RESA, 12(1), 69-92.

Piersanti, S. (2017). Servant leadership: The new leadership paradigm. Berrett Koehler Publishers Blog.

Pounder, J. (2001). "New leadership" and university organizational effectiveness: Exploring the relationship. Leadership and Organizational Journal, 22(6), 281-290.

Shahzad et al. (2013). Linking servant leadership with organizational citizenship behavior through trust: An embryonic structural modeling approach. European Journal of Social Sciences, 39(2), 273-284.

Sharon, N., Joseph, K., David, I. \& Kikelomo, E. (2016). Good governance and leadership: Pathway to sustainable national development in Nigeria. Journal of Public Administration and Governance, 6 (1), 35-49.

Spears, L. (2010). School of global leadership and entrepreneurship. Journal of Virtues and Leadership, 1(1), 2530.

Wong, P. \& Page, D. (2003). A conceptual framework for measuring servant leadership. Retrieved from www.twu.ca/Leadership 